\title{
Гендерна проблематика у фізичному вихованні. Історико-філософський аналіз
}

\author{
Оксана Марченко ${ }^{1}$ \\ Людмила Цикало' \\ Марія Бричук ${ }^{1}$ \\ Наталія Симоненко ${ }^{2}$
} Національний університет фізичного виховання і спорту України',
Київ, Україна

Полтавський університет економіки і торгівлі², Полтава, Україна

Мета: проведення історико-філософського аналізу гендерної проблематики у фізичному вихованні та 3'ясування сутнісно-змістовної характеристики категорії «гендер» у сфері фізичної культури і спорту.

Матеріал і методи: для розв'язання поставлених завдань, з метою узагальнення досвіду науковців, які займаються вивченням проблеми гендерного підходу у навчанні та вихованні, сучасних підходів до розвитку та вдосконалення системи фізичного виховання використовувався комплекс наступних теоретичних методів: аналіз, порівняння, узагальнення, систематизація, теоретичне моделювання.

Результати: проаналізовано історичний аспект виникнення гендерного підходу у фізичному вихованні, який має певні відмінності та особливості, що робить його окремим напрямком гендерного пізнання, згідно з яким усі педагогічні та соціокультурні аспекти у фізичному вихованні молоді можуть мати гендерний вимір. Теоретично обгрунтовано потребу виокремлення і трактування гендерного підходу як дефініції в політичному, громадському, соціальному середовищах, указано на його значення для фізичного виховання і спорту та запропоновано для використання в дослідженнях новий термін, що дозволяє його характеризувати як міждисциплінарне та крос-секторальне поняття, екстрапольоване, взаємопов'язане та відповідне розвитку фізичної культури та спорту в країнах розвиненої демократії.

Висновки: на основі отриманих результатів дослідження та вже наявних теоретичних і методологічних праць із гендерної проблематики обгрунтовано необхідність і доцільність розробки й упровадження гендерного компоненту у фізичне виховання сучасної молоді як сутнісно новий і прогресивний напрям аксіологічної значущості фізичної культури. Надана змістовна характеристика категорії «гендер» в сфері фізичної культури і спорту в контексті психолого-педагогічних досліджень.

Ключові слова: гендер, гендерний підхід, фізичне виховання, фізична культура, спорт, історія.

\section{Вступ}

За останні десятиліття гендерна проблематика постійно перебуває в центрі уваги сучасного європейського співтовариства, яке формує гендерно-правовий простір, враховуючи гендерний аспект країн, що приєднуються до нього. Але гендерна (паритетна) демократія важлива не лише задля міжнародного визнання, але і для розвитку внутрішньої динаміки Української держави, яка тривалий час рухається в напрямку забезпечення рівності всіх членів суспільства як невід'ємного складника національних зобов'язань, відображених, зокрема, у Законі «Про забезпечення рівних прав і можливостей жінок та чоловіків» [15]. Новим Законом України «Про освіту» передбачена норма про обов'язковість здобуття учнями гендерної компетентності - здатності усвідомлювати рівні права і можливості. Зокрема, документ передбачає розширення практики включення гендерного компоненту до освітніх програм, впровадження гендерного підходу в нормативно-правових актах у сфері освіти, а також підготовку фахівців із питань гендерної рівності та формування професійної спільноти [29, 24, 25]. У цьому зв'язку метою національної освіти нині проголошено пріоритет особистісної орієнтації на розвиток дитини, як суб'єкта власного життя, креативної, самодостатньої особистості, яка відповідає релевантним принципам гендерного підходу до виховання [36]. Доктор психологічних наук, професор О.М. Кікінежді слушно зауважує, що найбільш співзвучними нашому часу й перспективам формування гендерної культури у дітей та молоді є оновлення традицій та впровадження інновацій у контексті спадщини видатних українських педагогівгуманістів - В. Сухомлинського, Г. Ващенка, А. Макаренка, М. Драгоманова, К. Ушинсь-кого, та ін. [17].

Особливо актуальним на сьогоднішній день ми вважаємо можливість реалізації гендерного підходу у фізичному вихованні, який розглядається як вид діяльності, що сприяє не тільки формуванню фізичних, моральних та психічних якостей особистості, але й завдяки систематичній спеціально-організованій рухової 
активності допомагає виявити в освітньо-виховному процесі гендерні відмінності школярів різної статі, визначаючи роль фізичного виховання в гендерній соціалізації школярів. Системний аналіз світового масиву наукових знань та міжнародного досвіду вивчення гендерної проблематики свідчить про певні теоретичні напрацювання у висвітленні цього процесу. Проблеми формування гендерної культури молоді досліджують Т.В. Говорун, О.М. Кікінежді, О.Б. Кісь, Н.М. Лавриненко, П. Кравець, О.А. Луценко, О.С. Цокур та інші науковці $[2,7,17,29]$. Важливий внесок у розробку гендерного підходу в педагогічній освіті належить О.А. Вороніній (проблеми розробки теорії і методології гендерних досліджень, визначення місця й ролі гендерного виховання в системі професійної підготовки студентів) [5]; Л.В. Штильовій (розробка методичних програм для вчителів із питань впровадження гендерної освіти і виховання в середній школі) [43]; І.С. Кльоциній (накреслення шляхів гендерної соціалізації особистості з урахуванням вікових особливостей, розробка практикуму з гендерної проблематики для студентів з метою подолання гендерних стереотипів) $[18,19]$. Розвідка А.Л. Ворожбітової (2008) репрезентує гендерний підхід до професійної діяльності фахівця з фізичної культури [6]. Реалізації гендерного підходу до навчання та виховання присвячені праці М. М. Куїнджі та Є.Д. Лапонової (2005), Н.В. Козловської (2006), С.А. Чубарової (2007), В.Д. Єремєєвої (2008), Л.В. Тарасенко (2007) [29]. Вчені-юристи та політичні діячі в Україні також опікуються питаннями гендерної проблематики та є розробниками і дослідниками гендерного напряму сучасній вітчизняній правовій доктрині: Н.М. Оніщенко, І.В. Суслова, С.В. Береза [31].

У сучасних дослідженнях І.В. Євстігнєєвої (2012) доведено, що основними критеріями гендерного виховання учнів основної школи в процесі фізичного виховання $€$ когнітивний, емоційно-ціннісний, мотиваційний та поведінковий [14]. О.В. Фащук (2011) обґрунтовано особливості ставлення підлітків до уроку фізичної культури з урахуванням гендерної ідентифікації [40]. Г.Ф. Дульмухаметова (2011) довела існування бар'єрів щодо реалізації статевої диференціації навчання молодших школярів у навчально-виховному процесі [13]. А.С. Дамадаєва (2010) при аналізі досліджень гендерної диференціації та соціалізації в спорті не виявила загальних закономірностей [12]. У праці В.І. Лукащук (2012) зазначено, що спорт як діяльність формує андрогінний тип особистості у жінок та призводить до підсилення маскулінності у чоловіків [28]. Гендерні особливості при виборі видів спорту, прояв психофізичних і рухових здібностей юнаків і дівчат вивчали M. Slingerland, L. Haerens, G. Cardon, L. Borghouts (2014), B. Antala, V. Dancikova (2012), Wenchao Li (2013), E. Miloshova (2012), J. Sedlacek, P. Jankovsky, M. Zvonar (2012), S. Stavrev, V. Tsvetkov (2012) [29, 46, 51, 52].

Але, незважаючи на значну кількість праць з проблеми, мусимо констатувати відсутність системного комплексного підходу до вивчення історичних основ виникнення гендерного підходу до формування фізичної культури дітей, підлітків і молоді, що і визначило актуальність нашого дослідження.

Мета дослідження - вивчення історичних засад виникнення гендерного підходу у фізичному вихованні та з'ясування сутнісно-змістовної характеристики категорії «гендер» у сфері фізичної культури і спорту.

\section{Матеріал і методи дослідження}

Для розв'язання поставлених завдань використовувався комплекс таких методів: теоретичні (аналіз, порівняння, узагальнення, систематизація, теоретичне моделювання) проводились з метою узагальнення досвіду науковців, які займаються вивченням проблеми гендерного підходу у навчанні та вихованні, сучасних підходів до розвитку та вдосконалення системи фізичного виховання та визначення проблемного поля дослідження.

Наукова робота виконувалась в рамках теми, затвердженої Міністерством освіти і науки України: шифр 1.2 Ф. «Історичні та організаційно - методичні засади формування гендерного підходу у фізичному вихованні дітей, підлітків і молоді» № 0117U002386 УДК 796.011.3 053.2 / - 53.7:159.922.7 та згідно Плану НДР у галузі фізичної культури і спорту за темою 3.1 «Удосконалення системи педагогічного контролю фізичної підготовленості дітей, підлітків і молоді в закладах освіти» на 20212025 pp.

\section{Результати дослідження}

Гендерний підхід у сфері фізичної культури і спорту має певні особливості, що робить його окремим напрямком гендерного пізнання структурно-функціональних підходів, згідно з яким усі педагогічні та соціокультурні аспекти у фізичному вихованні молоді можуть мати гендерний вимір. Вивчаючи історію фізичного виховання молоді крізь призму гендера, українські та зарубіжні вчені наголошують на взаємозв'язку гендерного, диференційованого та особистісно-орієнтованого підходів як основи гуманізації навчально-виховного процесу [23, 39]. Заглиблення в історію розвитку філософії і педагогіки дає підстави для висновку про те, що всі великі і видатні педагоги, як правило, були водночас відомими філософами i, навпаки, - практично кожен великий філософ, як правило, завершував “будівництво” своєї філософської системи етикою, головний зміст якої складали вчення про мораль, теорія освіти і виховання [31]. Візьмемо, наприклад, античних мислителів: Фалеса і Демокріта, Сократа і Платона, Аристотеля і Парменіда. Хіба вони були лише філософами? Хіба вони не бачили життя? Хіба їх не цікавила доля людини, її навчання і виховання? Звичайно, були, бачили, цікавила. Їхні етичні погляди - це чиста (теоретична) педагогіка. Лише з тією різницею, що висловлювалася вона на відповідному категорійному рівні, систематизовано і у відповідності до загально-світогляднх установок тієї доби [31, 41]. 3 античності в суспільстві виступала нерівна цінність чоловіків і жінок, що мотивувалося їх різною природою, оскільки жінка «завжди експліцитно або імпліцитно кодувалася в поняттях емоційності, чуттєвості, тілесності», що незмінно отримувала негативну поляризацію, в античності будучи протилежністю найбільших цінностях: розумного і духовного, який уособлював чоловіче начало [2, 25, 29].

Зокрема, в античні часи Платон Афінський (427-347 рр. до н.е.) увів поняття «андрогіни», висловивши ідею рівноправності статей. Його ставлення до жінки було суперечливим. 3 одного боку, мислитель вважав її нижчою істотою. 3 другого боку, в описаній ним ідеальній державі жінка могла брати участь у всіх справах нарівні з чоловіком. Ці ідеї пізніше втіляться в працях багатьох 


\section{СЛОБОЖАНСЬКИЙ НАУКОВО-СПОРТИВНИЙ ВІСНИК}

фахівців, у тому числі і з гендерної психології [2, 29]. Міркування Арістотеля Стагірета (384-322 рр. до н.е.) про стосунки чоловіка й дружини в сім'ї, про обмеження народонаселення для гармонійних відносин у суспільстві, про поділ праці, як і раніше, викликають інтерес [2, $25,29]$. Він вважав, що успіх у державі може бути лише при невеликому населенні, тому чоловікам до 37 років не було дозволено мати дітей, а жінці - до 18 років. Історія філософії, в рамках якої довгий час розвивалися педагогіка і психологія, показує, що в усі періоди розвитку суспільства виховання хлопчиків відрізнялося від виховання дівчат [42].

Фізичне виховання, як спеціалізована сфера суспільної діяльності, відокремлене від фізичної праці, з'явилося більше 8 тис. років тому. У цей час статевовікові обряди ініціації були пов'язані з переходом юнаків дівчат у доросле життя. Доти вони мали оволодіти відповідними знаннями і навичками племінного життя, набути необхідної фізичної і моральної зрілості [22, 23, 26, 29].

3 огляду на проблему нашого дослідження, на основі ретроспективного аналізу простежимо історико-педагогічні та культурні передумови виникнення гендерного підходу у фізичному вихованні. Загалом фізичне виховання в античному світі виявлялось у двох системах: спартанській та афінській. У період розквіту еллінської культури в Греції існували два міста-держави з відмінними системами фізичного виховання, які стали зразком для інших міст Стародавньої Греції: це Спарта і Афіни [26]. Згідно традиціям і законам спартанська жінка повинна була, як і чоловіки, відвідувати гімнастичний зал, щоб підтримувати себе на благо держави і сім'ї в хорошій фізичній формі. 3 дитинства дівчинки, як і хлопчики, і разом з хлопчиками, оголивши, як і вони, торс, займалися фізичною культурою. Жінки, дружини і матері, брали участь у вихованні хлопчиків відважними воїнами, дівчат - готовими до самопожертви патріотками Спарти. Фізичне виховання було засновано на таких вправах, як біг, боротьба, метання диска і списа, і було обов'язковим для обох статей.

У Стародавньому Єгипті з IV-го до початку III-го тисячоліття до н.е. був досить високий рівень сімейного виховання і навчання. Відносини між жінкою і чоловіком в сім'ї будувалися на рівноправній основі, тому і дівчатам, і хлопцям приділялася однакова увага. До 4 років дітей вчила мати вдома, потім і дівчатка і хлопчики відвідували загальну школу. Крім вивчення наук, юнаки з вищого класу суспільства займалися фізичними вправами - плаванням, стрільбою або бігом. Історія свідчить, що вже в той час види рухової активності у хлопців і дівчат відрізнялися. Якщо єгипетські хлопці грали частіше в рухливі ігри, змагалися в силі та спритності, то дівчата, не нехтуючи, звичайно, і подібними заняттями, обожнювали танці [9, $10,26]$. В історії древньої Індії (VI ст. до н.е. і до VIII ст. н.е.) жінки ведичної епохи користувалися більшими правами, ніж жінки Греції, Риму, держав Середземномор'я.

Стосунки двох статей у стародавньому Китаї виражаються за допомогою аналогії, метафори і символів. Вони чітко втілюють особливості природного і соціального порядку в одній людині. Інь і Янь символізують взаємодоповнення, взаємозалежність та взаємоперетворення. Класифікація на Інь і Янь $є$ відносною. Кордон між Інь і Янь змінюється в залежності від статі, віку і статусу людей. По відношенню до чоловіка, жінка знаходиться в підлеглому положенні, але по відношенню до сина і слуги
- в домінуючому, на правах матері і господині. Стародавня китайська міфологія стверджує, що будь-яке людське тіло містить в собі і чоловіче, і жіноче начало. 3 цих уявлень виходив і К. Юнг, стверджуючи, що в колективному несвідомому кожного індивіда присутні два різних архетипи: «душа» (аніма), персоніфікує жіноче начало - смутні почуття і настрої, передчуття, здатність любити, почуття природи і т. п., i «дух» (анімус) - фізична сила, ініціатива, раціональність [44]. Чоловік повинен виражати свої фемінінні якості поряд з маскулінними, а жінка повинна проявляти свої маскулінні якості, також як і фемінінні. Якщо ж ці необхідні атрибути залишаються нерозвиненими, результатом з'явиться одностороннє зростання і функціонування особистості. Тільки поєднання душі і духу забезпечує гармонійний розвиток індивіда [45].

Фізичне виховання в Середньовіччі ще більшою мірою відокремлюється від трудової та військової діяльності. Так, у ранній період феодалізму вплив на фізичне виховання мали різні релігійні напрямки, які в цілому (за винятком буддизму) негативно ставилися до нього.

Появою теоретичних трактатів письменників, гуманістів, соціалістів-утопістів, педагогів, лікарів про організацію фізичного виховання визначався період Епохи Відродження (XIV - XVI ст.). До середини XVII ст. з'являються перші спроби введення фізичного виховання в режим шкільного дня. Фундаментом для розвитку природничо-наукових основ фізичного виховання були праці з анатомії і біомеханіки Леонардо да Вінчі (1452 1519), з анатомії - Андреа Везалія (1514 - 1564) і фізіології - Вільяма Гарвея (1578 - 1657) [9, 10, 32]. Таким чином, вже в стародавньому світі система виховання дітей різної статі будувалася на основі диференційованого підходу, в основі якого був традиційний розподіл соціальних ролей чоловіка та жінки в суспільстві, усунення жінки від діяльності поза сімейним вогнищем. Фізичне виховання, в першу чергу, було націлене па підготовку дитини до ролі чоловіка або жінки.

Великий внесок у розвиток фізичного виховання Нового часу (XVII-XVIII ст.) належить чеському педагогу Я. А. Коменському (1592-1670), який розробив та запропонував класно-урочну систему навчання, а також вважав, що дівчата повинні отримувати освіту нарівні з хлопчиками. Учений рекомендував будувати процес навчання, виховання та фізичного розвитку, використовуючи систему педагогічних спостережень з обов'язковим урахуванням вікових та індивідуальних особливостей дітей [37].

Проведений аналіз різних педагогічних систем показав, що взагалі до XVIII століття громадському вихованню дівчат не надавалося великого значення, так як головним завданням жінки вважалось продовження роду. I тільки лише в XVIII столітті громадські діячі, філософи, представники природничо-наукових дисциплін стали розглядати можливість цілеспрямованого виховання дівчат не тільки для сімейного життя, а й для громадської діяльності [42]. Подальший розвиток гуманітарних та природничих наук в епоху Просвітництва призвів до того, що видатні педагоги, лікарі та філософи почали розглядати фізичне виховання як невід'ємну складову всебічного виховання члена суспільства. I на відміну від Стародавніх часів, фізичному вихованню дівчат стали приділяти більшу увагу. Отже, історичні факти свідчать, що на різних етапах становлення людства, відношення до занять фізичним вихованням обох статей зміню- 
валось, але головним був диференційований підхід, в основі якого полягав традиційний розподіл соціальних ролей чоловіка та жінки у суспільстві.

Теорію статево-диференційованого виховання розробив Ж. Ж. Руссо у XVIII ст., головна ідея якого була зумовлена зв'язком між поведінкою та життєвою стратегією людини відповідно до її біологічної статі. Тобто йдеться про визнання пріоритету біологічної статі над соціальною [43]. У своїх працях Ж. Ж. Руссо наголошував як на неможливості одну стать вважати кращою за іншу, так і на неможливості їх урівноваження. Мета, методи та підходи до виховання хлопчиків та дівчат повинні бути різними тому, що біологічні статеві відмінності містять у собі різні емоційні, пізнавальні та особистісні характеристики. Ґрунтуючись на цих постулатах, учений вважав за необхідне з перших днів життя дитини впроваджувати диференційоване виховання юнаків і дівчат [3, 21, 29].

У XVI-XVIII століттях вітчизняна теорія і практика фізичного виховання значною мірою формувалася під впливом праць російського педагога, анатома і лікаря П.Ф.Лесгафта (1837-1909). У фундаментальний праці «Керівництво з фізичної освіти для дітей шкільного віку» він науково обґрунтував концепцію фізичного виховання людини [27]. Він стверджував, що системи фізичного виховання підпорядковані закономірностям фізіології. Паралельно з розвитком фізіології постійно повинні переглядатися та удосконалюватися фізичні вправи [23]. Свої педагогічні погляди П. Ф. Лесгафт реалізовував в процесі підготовки керівниць фізичної освіти [27].

У другій половині XIX століття в багатьох країнах світу особливу гостроту набула проблема виховання і освіти жінок, а також їх участі в різних видах тілесно-рухової практики. В рамках Нового часу в західно-європейській філософсько-антропологічній думці актуальним завданням для урядів європейських країн, в тому числі й України, стало фізичне виховання підростаючого покоління і особливо жінок. Однак серед основних завдань жіночої освіти в нашій державі не було виховання повноправного члена суспільства. В жінці бачили, перш за все, продовжувачку роду, і саме тому вважалося важливим дбати про її здоров'я. Разом з тим, в даний період, у світовій науці виникає велика кількість різноманітних, часто суперечливих між собою теорій статі [2, 21, 29].

Наприкінці XIX - початку XX століття в багатьох країнах Заходу змінилася ситуація в суспільстві: у Франції, Англії та США набрав розмаху рух за звільнення жінок. Але, не дивлячись на те, що феміністки домоглися права участі в муніципальних виборах та бути шкільними вчителями, навряд чи можна стверджувати, що жінка стала рівноправною з чоловіками [2, 29]. Отже, перераховані вище зміни в нашій та західно-європейській культурі проникають в більш широкі соціальні верстви, створюючи основу суспільних взаємовідносин, що стало передумовою у суспільстві для виникнення гендерного підходу. Щодо фізичного виховання, то у всьому світі воно отримало статус навчального предмета. У медицині визнали лікувальну фізичну культуру, почалося вивчення різноманітних психічних явищ, які відбуваються під впливом фізичних навантажень [9, 10]. Спортивні заходи стали мати емоційний вплив на людину так само, як і мистецтво. Представники різних класів та різної статі знаходили у фізичній культурі засоби для захисту власних інтересів. У більшості публікацій і висловлювань того часу була присутня досить істотна обмовка про те, що фізичні вправи не повинні завдавати шкоди жіночності [7, 29].

На початку XX століття проблеми психології статі і міжстатевих відносин в нашій державі практично не досліджувалися, оскільки психологічна наука в Україні проходила етап інституціоналізації, який супроводжувався науковими та організаційними перетвореннями. Природно, що в цей період вітчизняних публікацій з психології статі не було, а увагу вчених привертали роботи зарубіжних дослідників: З. Фрейда, К. Юнга та багатьох інших. Про статус і ролі жінки в суспільстві, про їі психологічні характеристики у порівнянні з характеристиками чоловіків в цей час міркували в основному не психологи, а громадські діячі, філософи, представники природничо-наукових дисциплін [34].

Подальший розвиток фізичного виховання у XX-XXI ст. характеризується відповідно до соціокультурних і гуманістично-орієнтованих змін в житті нашого суспільства. Професорка Оксана Вацеба, досліджуючи історію розвитку фізичної культури і спорту в Україні, виявила, що перші фундаментальні праці з теоретичних основ фізичного виховання та спортивного тренування з'явилися на початку 30-х років. Серед них, працями, які узагальнюють теорію спортивного тренування є: Г. Госке «Тренировка к соревнованиям» (Харків, 1929), Д. Крадман «Женщина в спорте» (Харків, 1931) [4]. Спостерігаються кардинальні зміни історично сформованих соціальних ролей чоловіка та жінки, трансформація образів фемінності - маскулінності та формування гендерної культури людей. Суто феміністичні погляди історично передували гендерним процесам. Поширені у 60-80их роках минулого століття, вони вимагали поліпшення становища жінки та захисту її прав [21]. Надто поляризовані та звернені до проблем лише одної статі ці процеси виконали свою роль: подолали значний дисбаланс соціально-статевих відносин та привернули увагу світового співтовариства до проблем жінок [20].

Безперечно, еволюційність гендерного розвитку, його історичність має велике позитивне значення, оскільки ламає усталені у суспільному менталітеті уявлення щодо владної керівної ролі чоловіків і другорядної - жінок, практично у всіх сферах суспільного життя, що стосується також і фізичної культури і спорту. У цей час жінки активно долучаються до спорту, який є тією сферою, де дуже відчутно проявляється соціальна зумовленість конструювання жіночності та маскулінності, традиційні ґендерні стереотипи та ґендерно зумовлена поведінка. Наприклад, до 1952 року до олімпійських змагань з кінного спорту допускалися лише чоловіки, службовці в кавалерії. I тільки до Олімпіади в Гельсінкі обмеження за гендерною та професійними ознаками були зняті. Проте, і дотепер існують певні види, які характеризуються як більш чоловічі або жіночі.

У другій половині XX ст. гендерні дослідження активізувалися та вийшли на суттєво новий рівень. Своєрідною революцією, що відбулася в психології статевих ролей і виникненню «нової психології статі» сприяли три фундаментальних дослідження, висновки яких спростовують основні положення традиційної теорії. Це роботи Е. Маккобі і К. Джеклін та Дж. Мані і А. Ерхарда, які показали могутність ефекту соціалізації. Також значущою була наукова робота С. Бем, яка довела неспроможність протиставлення традиційною психологією маскуліннос- 


\section{СЛОБОЖАНСЬКИЙ НАУКОВО-СПОРТИВНИЙ ВІСНИК}

ті і фемінінності $[29,47]$. Проаналізувавши 1600 досліджень психологічних статевих відмінностей, проведених за сім років, Е. Маккобі і К. Джеклін прийшли до висновку, що, по суті, немає фундаментальних вроджених відмінностей в психологічних особливостях чоловіків і жінок в багатьох сферах дослідження, де раніше ці відмінності визнавалися; ті ж відмінності, які є у маленьких дітей, недостатні, щоб обгрунтовувати традиційну нерівність статевих соціальних ролей, що існує в буржуазному суспільстві [2]. За даними журналу «Psychological Abstracts», упродовж 1950-1980 рр. було опубліковано 30 тисяч робіт з проблеми статевих відмінностей $[2,7,29]$.

Починаючи з 60-70 рр. минулого століття у зарубіжній психології, та з 90-х рр. у вітчизняній психології, стали з'являтися роботи, що включають такі поняття як «гендер», «гендерний аналіз», «гендерний підхід», «гендерна соціалізація» тощо [21, 25, 29]. Гендерна психологія заявила про себе як про окрему галузь психологічного знання, завдяки чому організація досліджень в області статевих відмінностей вийшла на якісно новий рівень. Першим, хто ввів поняття гендеру, гендерної ідентичності, гендерної ролі для опису внутрішнього стану особистості з точки зору відчуття себе чоловіком або жінкою, був Джон Мані (Money, 1955). Об'єднавши вже наявні мізерні дані з результатами власних клінічних досліджень, Мані та його колеги почали розробляти модель процесу формування приналежності людини до чоловічої або жіночої статі або придбання якостей, типових для обох статей. Таким чином, термін «гендер» був включений в науковий контекст, перш за все, для того, щоб підкреслити не природну, а соціокультурну причину міжстатевих відмінностей. Один 3 найавторитетніших соціологів сучасності англієць Ентоні Гідденс пояснює, що «гендер» - це не фізичні відмінності між чоловіком і жінкою, а соціально сформовані особливості мужності і жіночності. Гендер, за його словами, означає, перш за все, соціальні очікування щодо поведінки, розглядається як відповідне для чоловіків і жінок [8]. В українській «Енциклопедії освіти» зазначено, що ґендерні відмінності - це не біологічна відмінність чоловіків і жінок, а соціально-психологічна різниця між жіночими й чоловічими ролями, які виконують у соціумі його члени [35]. Аналіз генезису гендерних підходів дав нам змогу визначити, що за досить нетривалий час свого існування він був розвинутий практично у всіх галузях вітчизняних наук. Тож маємо говорити про доцільність та необхідність його впровадження у процес фізичного виховання молоді.

Систематизуючи в історичному ракурсі появу і трактування дефініцій «гендеру», в результаті інтерпретації літературних джерел із проблем трактування цього поняття констатуємо його різне тлумачення. Зазначимо, що поняття «гендер» може розглядатись як історична та соціальна категорія. Природна гендерна ієрархія пов'язується з функціонально-рольовою моделлю поведінки. Тому гендер, будучи культурно та історично зумовленим феноменом, визначається не біологічно, а соціокультурно. Він також тлумачиться як сукупність уявлень про особистісні та поведінкові особливості чоловічого та жіночого $[24,25,29]$. У праці «Стать і гендер» $€$. П. Ільїн, покликаючись на зарубіжних авторів, зазначав, що поняття «стать» містить риси, безпосередньо зумовлені біологічною природою, тоді як «гендер» передбачає ті аспекти чоловічого й жіночого, причини яких ще не відомі [16]. Відтак, на відміну від статі, гендер є психологічним явищем, що належить до засвоєних форм поведінки й установок, пов'язаних із біологічною статтю [7 ]. Слід констатувати, що дефініції гендеру в різних царинах суспільних знань досі не набули усталеного і загальновизнаного тлумачення, що, зрештою, свідчить про недостатній рівень розвиненості аналізованого наукового напряму. Використовуючи обґрунтований зміст дефініцій гендеру, ми систематизували та розширили його тлумачення щодо запровадження у сфері фізичної культури і спорту.

Отже, нами теоретично обґрунтовано потребу виокремлення і трактування гендерного підходу як дефініції в політичному, громадському, соціальному середовищах, указано на його значення для фізичного виховання і спорту та запропоновано для використання в дослідженнях новий термін, що дозволяє його характеризувати як міждисциплінарне та крос-секторальне поняття, екстрапольоване, взаємопов'язане та відповідне розвитку фізичної культури та спорту в країнах розвиненої демократії. Зазначимо, що під цим поняттям слід розуміти змодельовані суспільством поведінкові взірці жінки та чоловіка, екстрапольовані на різні сфери суспільних відносин, у контексті нашого дослідження - відносини у сфері фізичної культури та спорту [24, 25].

\section{Висновки / Дискусія}

Отже, розвиток фізичного виховання був історично детермінований як соціальними факторами, так і біологічно-фізіологічними. Вони включають у себе взаємопов'язані компоненти, які мають суттєвий вплив на етапність формування фізичної культури особистості в її аксіологічній значущості. Це забезпечує цілісність процесу формування гендерного підходу у фізичному вихованні школярів, завершеність на кожному етапі, спадкоємність етапів, що досягається відповідністю віковим особливостям рівня і співвідношення природної, соціальної та культурної сторін фізичної культури особистості і домінантним видам діяльності. Таким чином, гендерна проблематика у фізичному вихованні стала глибшою за розумінням, ширшою за обсягом сфер її застосування, крім того, з'явились нові аспекти її реалізації [31]. Безперечно, еволюційність гендерного підходу, його історичність має велике позитивне значення, оскільки ламає усталені у суспільному менталітеті уявлення щодо владної керівної ролі чоловіків і другорядної - жінок практично у всіх сферах суспільного життя, в тому числі і в сфері фізичної культури і спорту. Проаналізувавши значну кількість наукових та науково-популярних психологічних джерел, І. С. Кльоцина зауважує, що «..більшість психологів, які опублікували дослідження за проблемою відмінностей між чоловічою та жіночою статями, виходять із положення, що анатомо-фізіологічні відмінності між людьми різної статі закономірно мають визначити відмінності в їх психологічній сфері». На думку професорки, більшість із таких праць не можна вважати гендерно-орієнтованими, незважаючи на те, що в їхній назві навіть $€$ слово «гендер» $[18,19,33]$. Вона пояснює, що така позиція психологів зумовлена глибоко вкоріненими уявленнями про те, що ознака статі - це обов'язкова відмінність не тільки на рівні прояву людини як індивіда, але і на таких рівнях як особистість, суб'єкт діяльності, індивідуальність [18, 19].
Марченко, О., Цикало, Л., Бричук, М., Симоненко, Н. (2020), «Гендерна проблематика у фізичному вихованні. Історико-філософський аналіз»
Слобожанський науково-спортивний вісник, № 6(80), С. 22-31, doi:10.15391/snsv.2020-6.004 
Це твердження вважає досить суперечливим група науковців на чолі з І.В. Грошевим. Так, за даними дослідника, сьогодні світова література налічує понад 50000 праць, в яких автори констатують наявність статевих відмінностей у різноманітних сферах онтогенезу людини [11, с. 10]. Проаналізувавши близько 4000 джерел, I. В. Грошев виявив у них констатацію більш ніж 2500 статевих відмінностей. [11]. Продовжуючи слушну думку вченого, слід зазначити, що індивідуально-психологічні властивості людини від її народження організовані у визначені програми, завдяки яким соціальні фактори відразу після народження, а можливо, і ще до народження, у внутрішньоутробний період, «натрапляють» не на аморфну біологію людини, а на специфічну людську біологію [11, с.29 ]. Тож вплив статі на розвиток людини (у нашому випадку - безпосередньо, на розвиток фізичних якостей) досить значний. Змінити її не можна, оскільки стать - наперед визначена від народження даність.

Підтвердження нашої точки зору шукаємо у видатного вченого-психолога Б. Г. Ананьєва, який займався вивченням статевих характеристик як індивідуальних властивостей людини та їх зв'язку з особливостями її соціальної поведінки: «Стать - це одна з фундаментальних координат індивідуальності, яка пронизує всі властивості людини, а саме координата статево-вікової змінності, яка має генетичну, конституціональну вроджену програму та природно обумовлену диспозицію людей у поведінці та діяльності» [1, с. 169]. Цілком закономірно, що заняття фізичною культурою і спортом пов'язані з проявом фізичних можливостей людини і великою мірою визначаються її біологічною статтю. Однак, вивчаючи дану проблему, ми приходимо до висновку про те, що не можна ігнорувати біологічні або соціальні фактори, їх необхідно розглядати в тісному взаємозв'язку [24, 25]. На наше переконання, під час організації процесу фізичного виховання дітей, підлітків і молоді необхідно враховувати біологічну стать як основу диференціації рухового режиму (обсяг, інтенсивність, спрямованість тощо), а гендерні особливості інтересів, потреб, мотивів, ціннісних орієнтацій можуть мати як індивідуальний, так і груповий рівень прояву.

Перспективи подальших досліджень. Проведені дослідження не вичерпують проблему вивчення гендерного підходу у фізичному вихованні школярів, а ставлять ряд запитань, які торкаються засобів та методів у фізичному вихованні для формування індивідуальної фізичної культури особистості.

Конфлікт інтересів. Автори заявляють, що немає конфлікту інтересів, який може сприйматися як такий, що може завдати шкоди неупередженості статті.

Джерела фінансування. Ця стаття не отримала фінансової підтримки від державної, громадської або комерційної організації.

\section{Список посилань}

1. Ананьев Б. Г. (1980), Избранные психологические труды: Педагогика, Москва, 232 с.

2. Бендас Т. В. (2009), Гендерная психология: учебное пособие, Санкт-Петербург: Питер Пресс, 428 с.

3. Варена Э. (1999), К вопросу о становлении концепции женственности в буржуазном обществе 18 века: Пол. Гендер. Культура. Немецкие и русские исследования, С. 55-108.

4. Вацеба О. М., Герцик М. С. (2002), Вступ до спеціальностей галузі фізичне виховання і спорт: навчальний посібник, Львів: Українські технології, 230 с.

5. Воронина О. А. (2002), Гендер: словарь гендерных терминов, Москва, С. 21-22

6. Ворожбитова А. Л. (2011), Гендер в спортивной деятельности: учебное пособие, Москва: ФлинТА, 216 с.

7. Гендерні питання (2004), Проблеми освіти: наук.-метод. зб., Київ: Наук.-метод. центр вищої освіти, Вип. 36, 172 с.

8. Гіденс Е. (1999), Соціологія. Київ: Основи, 125 с.

9. Голощапов Б. Р. (2005), Історія фізичної культури і спорту, монографія, Академія, 312 с.

10. Григоревич В. В. (2008), Загальна історія фізичної культури: монографія, Радянський спорт, 228 с.

11. Грошев И. В. (2005), Психофизиологические различия мужчин и женщин: монографія, Воронеж: НПО «МОДЕК», 464 с.

12. Дамадаеева А. С. (2010), «Специфика гендерной дифференциации личности в спорте», Ученые записки университета им. П.Ф. Лесгафта, Вип. 10(68), 54 с.

13. Дульмухаметова Г. Ф. (2011), Педагогические условия половой дифференциации обучения младших школьников: диссертация, Казань: Татарский гос. гуманитарно-педагогический ун-т, 245 с.

14. Євстігнєєва І. В. (2012), Гендерне виховання учнів основної школи на уроках фізичної культури: автореферат, Луганськ, 24 с. (5):35.

15. Закон України «Про забезпечення рівних прав та можливостей жінок і чоловіків» (2018), Відомості Верховної Ради,

16. Ильин Е. П. (2010), Пол и гендер, Санкт-Петербург: Питер, 686 с.

17. Кікінежді О. М. (2009), Вісник післядипломної освіти.

18. Клецина И. С. (2004), Психология гендерных отношений: теория и практика, Санкт-Петербург: Алтейя, 408 с.

19. Клецина И. С. (2001), «О проблемах гендерной психологи», Мир психологи, Вип. 4, С. 162-208.

20. Котляр И. И. (2005), Права человека, Москва: Тессей, 158 с.

21. Круцевич Т. Ю., Марченко О. Ю. (2019), «Історичні засади формування гендерного підходу у фізичному вихованні», Фізичне виховання, спорт і культура здоров'я у сучасному суспільстві, Вип. 4 (44), С. 26-34.

22. Круцевич Т. Ю., Курамшин Ю. Ф., Петровський В. В. (2008), Теорія і методика фізичного виховання: Предмет і зміст теорії і методики фізичного виховання, Київ: Олімпійська література, Т. 1. Розділ 1, С. 9-22.

23. Круцевич Т. Ю. (2017), Теорія і методика фізичного виховання, Київ: Олімпійська література, 392 с.

24. Круцевич Т. Ю., Марченко, О. Ю. (2020), «Концептуальні підходи в дослідженнях гендерної диференціації у фізичному вихованні», Теорія і методика фізичного виховання і спорту, Вип. 2, С. 80-87.

Марченко, О., Цикало, Л., Бричук, М., Симоненко, Н. (2020), «Гендерна проблематика у фізичному вихованні. Історико-філософський аналіз»
Слобожанський науково-спортивний вісник, № 6(80), С. 22-31, doi:10.15391/snsv.2020-6.004 


\title{
СЛОБОЖАНСЬКИЙ НАУКОВО-СПОРТИВНИЙ ВІСНИК
}

25. Круцевич Т. Ю., Марченко О. Ю. (2019), «Концептуальні засади гендерного підходу у фізичному вихованні школярів», Спортивний вісник Придніпров'я, Вип. 2, С. 104-114.

26. Кулинко Н. Ф. (1997), Історія фізичної культури і спорту, Оренбург: Оренбургское книжкове видавництво, 374 с.

27. Лесгафт П. Ф. (1951), Избранные педагогические сочинения. Москва: АПН РСФСР, 399 с

28. Лукащук В. І. (2012), «Особливості гендерної соціалізації у спорті», Вісник Харківського нац. уні-ту ім. В.Н. Каразіна, Соціологічні дослідження сучасного суспільства: методологія, теорія, методи, № 993, вип. 29. С. 141-145.

29. Марченко О. Ю. (2018), Теоретико-методологічні основи гендерного підходу до формування аксіологічної значущості фізичної культури школярів: монографія, Переяслав-Хмельницький: Домбровська Я. М., 292 с.

30. Марченко О. Ю. (2018), «Характерні відмінності у виборі факторів здорового способу життя як складових індивідуальної фізичної культури сучасних школярів», Слобожанський науково-спортивний вісник, Вип. 6(68), С. 10-15.

31. Оніщенко Н., Береза С., Макаренко Л. (2009), «Гендерні дослідження в сучасному суспільстві: проблеми, реалії, перспективи», Журнал Верховної Ради України «Віче», Вип. 17, С. 25-28.

32. Пангелова Н. Є. (2007), Історія фізичної культури: навч. посіб., Київ: Освіта України, 288 с.

33. Пушкарева Н. Л. (2001), Гендерные исследования: рождение, становление, методы и перспективы в системе исторических наук. Женщина. Гендер. Культура. Москва, 21 с.

34. Практикум по гендерной психологии (2003), СПб.: Питер, 479 с.

35. Самойленко Н. І. (2016), «Передумови виникнення гендерного підходу у педагогічній науці», Молодий вчений, Вип. 6(33), С. 458-461.

36. Саух П. Ю. (2011), Інновації у вищій освіті: проблеми, досвід, перспективи, Житомир: ЖДУ ім. Івана Франка, 444 с.

37. Столбов В. В., Чудинов И. Г. (1962), История физической культуры, Москва: МГУ, 200 с.

38. Татаринцева Н. Е. (1999), Педагогические условия воспитания основ полоролевого поведения детей младшего дошкольного возраста: автореферат, Ростов-на-Дону, 18 с.

39. Томенко О. А. (2012), Неспеціальна фізкультурна освіта учнівської молоді: теорія і методологія: монографія, Суми: МакДен, 276 с.

40. Фащук О. В. (2011), Гендерні особливості фізичного виховання підлітків: автореферат, Івано-Франківськ: Прикарпатський нац. ун-т ім. Василя Стефаника, 24 с.

41. Філософія освіти (2009): навчальний посібник, Киїів: НПУ імені М. П. Драгоманова, 329 с.

42. Филиппова С. О. (2002), Физическая культура в системе образования дошкольников: автореферат, Санкт-Петербург, $40 \mathrm{c}$.

43. Штылева Л. В. (2001), Гендерный подход в дошкольной педагогике: теория и практика. Мурманск, С. 40-47.

44. Юнг К. Г. (1991), Архетип и символ, Москва: Ренесенс, 304 с.

45. Юнг К. Г. (1994), Проблемы души нашего времени, Москва: Прогресс, 219 с.

46. Antala B. (2012), «The impact of coeducational physical education to the class climate at secondary schools», Olimpik Sports and Sport for All. Sport, Street, Adaptatio : proceeding book of XVI International Scientific Congress and VI International Scientific Congress; 2012May 17-19; Sofia. Sofia: National Sport Academi «Vassil Leski», pp. 167-9.

47. Bem S. L. (1983), «Gender schema theory and its implications for child development: Raising gender - schematic chidren in a gender - schematic society", Journal of women in culture and society, issues 8(4), pp. 65-78.

48. Crum B., Mester J. (1994), A critical review of competing PE concepts. Sport scinces in Europe 1993 - Current and future perspectives. Aachen: Meyer and Meyer, pp. 516-533.

49. Krutsevych T. Yu., Marchenko O. Yu. (2017), «Age differenced of self-esteem of physical self at school», Gender aspects, issues 2(38), pp.112-116.

50. Krutsevych T., Turchyk Y., Lukianchenko M., Djatlenko S. (2010), «The peculiariarities of physical education program in Ukraine», European J. of Physical and Health Education, issues 5, pp. 16-21

51. Scott S. (1986), «Gender: a useful category of historical analisis», The American Historical Review, issues 5, pp. 10-67.

52. Slingerland M., Haerens L., Cardon G., Borghouts L. (2014), «Differences in perceived competence and physical activity levels during single gender modified basketball game playin middleschool physical education», European Physical Education Review, issues 20 , pp. 20-35

Стаття надійшла до редакції: 23.11.2020 p.

Опубліковано: 21.12.2020 p.

\begin{abstract}
Аннотация. Оксана Марченко, Людмила Цикало, Мария Бричук, Наталья Симоненко. Гендерная проблематика в физическом воспитании. Историко-философский анализ. Цель: проведение историко-философского анализа гендерной проблематики в физическом воспитании и выяснения сущностно-содержательной характеристики категории "гендер" в сфере физической культуры и спорта. Материал и методы: для решения поставленных задач с целью обобщения опыта ученых, занимающихся изучением проблемы гендерного подхода в обучении и воспитании, современных подходов к развитию и совершенствованию системы физического воспитания использовался комплекс следующих теоретических методов: анализ, сравнение, обобщение, систематизация, теоретическое моделирование. Результаты: исследован исторический аспект возникновения гендерного подхода в физическом воспитании, который имеет определенные отличия и особенности, что делает его отдельным направлением гендерного познания, согласно которому все педагогические и социокультурные аспекты в воспитании молодежи могут иметь гендерное измерение. Теоретически обоснована необходимость выделить и трактовать гендерный подход как дефиницию в политической, общественной, социальной средах, указать на его значение для физического воспитания и спорта. Предложено для использования в исследованиях новое междисциплинарное и кросс-секторальное понятие, экстраполированное, взаимосвязанное и соответствующее развитию физической культуры и спорта в странах развитой демократии. Выводы: на основе полученных результатов исследования и уже имеющихся в науке теоретических и методологических работ по гендерной проблематике, обоснована необходимость и целесообразность разработки и внедрения гендерного компонента в физическом воспитании современной молодежи как нового и прогрессивного направления аксиологической зна-
\end{abstract}

Марченко, О., Цикало, Л., Бричук, М., Симоненко, Н. (2020), «Гендерна проблематика у фізичному вихованні. Історико-філософський аналіз» 
чимости физической культуры. Предложена сущностно-содержательная характеристика категории «гендер» в сфере физической культуры и спорта в контексте психолого-педагогических исследований.

Ключевые слова: гендер, гендерный подход, физическое воспитание, физическая культура, спорт, история.

Abstract. Oksana Marchenko, Lyudmila Tsykalo, Maria Brychuk, Natalia Symonenko. Gender problems in physical education. Historical and philosophical analysis. Purpose: historico-philosophical analysis of gender issue in physical education and clarification of the meaningful characteristics of the category "gender" in the field of physical culture and sports. Material and methods: to achieve objectives of the research and for generalization the experience of those scientists who investigate educational problems of the gender approach, modern approaches to development and improvement of physical education we used such theoretical research methods as analysis, comparison, generalization, systematization, theoretical modeling. Results: the historical aspect of the beginning of the gender approach in physical education has certain differences and features that makes it a separate area of gender cognition according to which all pedagogical and socio-cultural aspects of youth physical education can have a gender dimension. The necessity of distinguishing and interpreting the gender approach as a definition in political, public and social environments is theoretically grounded, its significance for physical training and sports is indicated, and a new term is suggested for use in research, which allows characterizing it as an interdisciplinary and cross-sectoral definition, extrapolated, interconnected and corresponding to the development of physical education and sports in the countries of developed democracy. Conclusions: acording to the results which were obtained during the research and the theoretical and methodological papers of the gender problem the necessity and expediency of the development and introduction of the gender component in the physical education of modern schoolchildren as an essentially new and progressive direction of the axiological significance of physical culture is justified. The essential and substantive characteristics of the category "gender" in the field of physical culture and sports in the context of psychological and pedagogical research are given.

Keywords: gender, gender approach, physical education, physical culture, sports, history.

\section{References} Russ.).

1. Ananev, B. G. (1980), Izbrannye psikhologicheskie trudy [Selected psychological works], Moskva: Pedagogika, 232 p. (in

2. Bendas, T.V. (2009), Gendernaia psikhologiia [Gender psychology]: uchebnoe posobie, Sankt-Peterburg: Piter Press, 428 p. (in Russ.).

3. Varena Erik-Khefeli (1999), K voprosu o stanovlenii kontceptcii zhenstvennosti v burzhuaznom obshchestve 18 veka [On the formation of the concept of femininity in the bourgeois society of the 18th century], Pol. Gender. Kultura. Nemetckie i russkie issledovaniia, pp. 55-108. (in Russ.).

4. Vatseba, O. M. (2002), Vstup do spetsialnostei haluzi «fizychne vykhovannia i sport» [Introduction to the specialties of «physical education and sports»]: navch. posib, Lviv : Ukrainski tekhnolohii, 230 p. (in Ukr.).

5. Voronina, O. A. (2002) Gender. Slovar gendernykh terminov [Gender. Glossary of gender terms.], Moskva, pp. 21-22. (in Russ.).

6. Vorozhbitova, A. L. (2011), Gender v sportivnoi deiatelnosti [Gender in sports]: uchebnoe posobie, Moskva: FLINTA, 216 p. (in Russ.).

7. Henderni pytannia (2004), Problemy osvity [Gender issues. Problems of education]: nauk.-metod. zb. issues. 36. Kyiv: Nauk.metod. tsentr vyshchoi osvity, 172 p. (in Ukr.).

8. Hidens, E. (1999), Sotsiolohia [Sociology], Kyiv: Osnovy, 726 p. (in Ukr.).

9. Holoshchapov, B. R. (2005), Istoriia fizychnoi kultury i sportu [History of physical culture and sports]: monohrafiia, Akademiia, 312 p. (in Ukr.)

10. Hryhorevych, V. V. (2008), Zahalna istoriia fizychnoi kultury [General history of physical culture]: monohrafiia, Radianskyi sport, 228 p. (in Ukr.).

11. Groshev, I. V. (2005), Psikhofiziologicheskie razlichiia muzhchin i zhenshchin [Psychophysiological differences between men and women]: Voronezh: Izdatelstvo NPO «MODEK», 464 p. (in Russ.).

12. Damadaeeva, A. S. (2010), «Specificity of gender differentiation of personality in sports», Uchenye zapiski universiteta im. P.F. Lesgafta, issues 10(68), 54 p. (in Russ.).

13. Dulmukhametova, G. F. (2011), Pedagogicheskie usloviia polovoi differentciatcii obucheniia mladshikh shkolnikov [Pedagogical conditions of gender differentiation in teaching primary schoolchildren]: dissertatciia, Kazan: Tatarskii gos. gumanitarnopedagogicheskii un-t, 245 p. (in Russ.).

14. Yevstihnieieva, I. V. (2012), Henderne vykhovannia uchniv osnovnoi shkoly na urokakh fizychnoi kultury [Gender education of primary school students in physical education lessons]: avtoreferat, Luhansk; 24 p. (in Ukr.).

15. Zakon Ukrainy «Pro zabezpechennia rivnykh prav ta mozhlyvostei zhinok i cholovikiv». Vidomosti Verkhovnoi Rady. $2018 ;(5): 35$. p. (in Ukr.).

16. Ilin, E. P. (2010), Pol i gender [Sex and gender], Sankt-Peterburg: Piter, 686 p. (in Russ.).

17. Kikinezhdi, O. M. (2009), Visnyk pisliadyplomnoi osvity.

18. Kletcina, I. S. (2004), Psikhologiia gendernikh otnoshenii: teoriia i praktika [Psychology of Gender Relations: Theory and Practice], Sankt-Peterburg: Alteiia, 408 p. (in Russ.).

19. Kletcina, I. S. (2001), «On the problems of gender psychology», Mir psikhologii, issues 4, pp. 162-208. (in Russ.).

20. Kotliar, I. I. (2005), Prava cheloveka [Human rights], Moscva: Tessei, 158 p. (in Russ.).

21. Krutsevych, T. Yu., Marchenko, O. Yu. (2019), «Historical principles of forming a gender approach in physical education», Fizychne vykhovannia, sport i kultura zdorovia u suchasnomu suspilstvi, issues 4 (44), pp. 26-34 (in Ukr.).

22. Krutsevych, T. Yu., Kuramshyn, Yu. F, Petrovskyi, V. V. (2008), Teoriia i metodyka fizychnoho vykhovannia. Predmet i zmist teorii i metodyky fizychnoho vykhovannia [Theory and methods of physical education. The subject and content of the theory and methods of physical education.], Kyiv: Olimpiiska lit., T. 1. Rozdil 1, pp. 9-22. (in Ukr.). 


\section{СЛОБОЖАНСЬКИЙ НАУКОВО-СПОРТИВНИЙ ВІСНИК}

23. Krutsevych, T. Yu. (2017), Teoriia i metodyka fizychnoho vykhovannia [Theory and methods of physical education]: pidruch, T. 2. Kyiv: Olimpiiska lit., 392 p. (in Ukr.).

24. Krutsevych, T. Yu., Marchenko, O. Yu. (2020), «Conceptual approaches in studies of gender differentiation in physical education», Teoriia i metodyka fizychnoho vykhovannia i sportu, issues 2, pp. 80-87. (in Ukr.).

25. Krutsevych, T. Yu., Marchenko, O. Yu. (2019), "Conceptual principles of gender approach in physical education of schoolchildren», Sportyvnyi visnyk Prydniprovia: naukovo-praktychnyi zhurnal, issues 2, pp. 104-114. (in Ukr.).

26. Kulynko, N. F. (1997), Istoriia fizychnoi kultury i sportu [History of physical culture and sports], Orenburh: Orenburhskoe knyzhkove vydavnytstvo, 374 p. (in Russ.).

27. Lesgaft, P.F. (1951), Izbrannye pedagogicheskie sochineniia [Selected pedagogical writings], Moskva: APN RSFSR,399 p. (in Russ.)

28. Lukashchuk, V. I. (2012), «Features of gender socialization in sports», Visnyk Kharkivskoho nats. uni-tu im. V.N. Karazina. Sotsiolohichni doslidzhennia suchasnoho suspilstva: metodolohiia, teoriia, metody, No. 993, issues 29. pp. 141-145 (in Ukr.).

29. Marchenko, O. Yu. (2018), Teoretyko-metodolohichni osnovy hendernoho pidkhodu do formuvannia aksiolohichnoi znachushchosti fizychnoi kultury shkoliariv [Theoretical and methodological bases of the gender approach to the formation of axiological significance of physical culture of schoolchildren]: monohrafiia. Pereiaslav-Khmelnytskyi: Dombrovska Ya.M., 292 p. (in Ukr.).

30. Marchenko, O. Yu. (2018), "Characteristic differences in the choice of factors of a healthy way of life as components of individual physical culture of modern schoolboys", Slobozhanskyi naukovo-sportyvnyi visnyk, issues 6(68), pp.10-15. (in Ukr.).

31. Onishchenko, N., Bereza, S., Makarenko, L. (2009), "Gender research in modern society: problemy, realii, perspektyvy», Zhurnal Verkhovnoi Rady Ukrainy «Viche», issues 17, pp. 25-28 (in Ukr.).

32. Panhelova, N. (2007), Istoriia fizychnoi kultury [History of physical culture]: navch. posib. Kyiv: Osvita Ukrainy, 288 p. (in Ukr.).

33. Pushkareva, N. L. (2001), Gendernye issledovaniia: rozhdenie, stanovlenie, metody i perspektivy v sisteme istoricheskikh nauk. Zhenshchina. Gender. Kultura [Gender Studies: Birth, Formation, Methods and Prospects in the System of Historical Sciences. Female. Gender. Culture], Moskva, 21 p. (in Russ.).

34. Praktikum po gendernoi psikhologii [Workshop on Gender Psychology ] (2003) / Pod red. I.S. Kletcinoi. SPb.: Piter, 479 p. (in Russ.).

35. Samoilenko, N. I. (2016), «Prerequisites for the emergence of a gender approach in pedagogical science», Molodyi vchenyi, issues 6(33), pp. 458-461 (in Ukr.).

36. Saukh, P. Iu, redactor (2011), Innovatsii u vyshchii osviti: problemy, dosvid, perspektyvy [Innovations in higher education: problems, experience, prospects.], Zhytomyr: Vyd-vo ZhDU im. Ivana Franka, 444 p. (in Ukr.).

37. Stolbov, V. V., Chudinov, I. G. (1962), Istoriia fizicheskoi kultury [History of physical culture], Moskva: MGU, 200 p. (in Russ.).

38. Tatarintceva, N. E. (1999), Pedagogicheskie usloviia vospitaniia osnov polorolevogo povedeniia detei mladshego doshkolnogo vozrasta [Pedagogical conditions for the upbringing of the foundations of sex-role behavior in children of primary preschool age], Rostov-na-Donu, 18 p. (in Russ.).

39. Tomenko, O. A. (2012), Nespetsialna fizkulturna osvita uchnivskoi molodi: teoriia i metodolohiia [Non-special physical education of student youth: theory and methodology ], Sumy : Vyd-vo «MakDen», 276 p. (in Ukr.).

40. Fashchuk, O. V. (2011), Henderni osoblyvosti fizychnoho vykhovannia pidlitkiv [Gender features of physical education of teenagers], Ivano-Frankivsk: Prykarpatskyi nats. un-t im. Vasylia Stefanyka, 24 p. (in Ukr.).

41. Filosofiia osvity (2009): Navchalnyi posibnyk / Za zah. red. V. Andrushchenka, I. Peredborskoi. K. : Vyd-vo NPU imeni M. P. Drahomanova, 329 p. (in Ukr.).

42. Filippova, S. O. (2002), Fizicheskaia kultura v sisteme obrazovaniia doshkolnikov [Physical culture in the education system of preschoolers], Sankt-Peterburg, 40 p. (in Russ.).

43. Shtyleva, L. V. (2001), Gendernyi podkhod v doshkolnoi pedagogike: teoriia i praktika [Gender Approach in Preschool Pedagogy: Theory and Practice], Murmansk, pp. 40-47 (in Russ.).

44. lung, K. G. (1991), Arkhetip i simvol [Archetype and symbol], Moskva: Renesens, 304 p. (in Russ.). Russ.).

45. lung, K. G. (1994), Problemy dushi nashego vremeni [The problems of the soul of our time], Moskva: Progress, 219 p. (in

46. Antala B. (2012), «The impact of coeducational physical education to the class climate at secondary schools», Olimpik Sports and Sport for All. Sport, Street, Adaptatio : proceeding book of XVI International Scientific Congress and VI International Scientific Congress; 2012May 17-19; Sofia. Sofia: National Sport Academi «Vassil Leski», pp. 167-169 (in Eng.).

47. Bem S. L. (1983), «Gender schema theory and its implications for child development: Raising gender - schematic chidren in a gender - schematic society», Journal of women in culture and society, issues 8(4), pp. 65-78 (in Eng.).

48. Crum B., Mester J. (1994), A critical review of competing PE concepts. Sport scinces in Europe 1993 - Current and future perspectives. Aachen: Meyer and Meyer, pp. 516-533 (in Eng.).

49. Krutsevych T. Yu., Marchenko O. Yu. (2017), «Age differenced of self-esteem of physical self at school», Gender aspects, issues 2(38), pp.112-116 (in Eng.).

50. Krutsevych T., Turchyk Y., Lukianchenko M., Djatlenko S. (2010), «The peculiariarities of physical education program in Ukraine», European J. of Physical and Health Education, issues 5, pp. 16-21 (in Eng.).

51. Scott S. (1986), «Gender: a useful category of historical analisis», The American Historical Review, issues 5, pp. 10-67 (in Eng.).

52. Slingerland M., Haerens L., Cardon G., Borghouts L. (2014), «Differences in perceived competence and physical activity levels during single gender modified basketball game playin middleschool physical education", European Physical Education Review, issues 20, pp. 20-35 (in Eng.).

Received: 23.11.2020.

Published: 21.12.2020.

Марченко, О., Цикало, Л., Бричук, М., Симоненко, Н. (2020), «Гендерна проблематика у фізичному вихованні. Історико-філософський аналіз»
Слобожанський науково-спортивний вісник, № 6(80), С. 22-31, doi:10.15391/snsv.2020-6.004 


\section{СЛОБОЖАНСЬКИЙ НАУКОВО-СПОРТИВНИЙ ВІСНИК}

\section{Відомості про авторів / Information about the Authors}

Марченко Оксана Юріївна: д.фіз.вих., професор; Національний університет фізичного виховання і спорту України: вул. Фізкультури, 1, Київ-150, Україна, 03150.

Марченко Оксана Юрьевна: д.физ.восп., профессор; Национальный университет физического воспитания и спорта Украины: ул. Физкультуры, 1, Киев-150, Украина, 03150.

Oksana Marchenko: Doctor of Sciences (Physical Education and Sports), Professor; National university of Physical Education and Sport of Ukraine: 1 Fizkulturna Street, Kyiv-150, Ukraine, 03150.

ORCID.ORG/0000-0002-2902-5960

E-mail: o.mar4enko17@gmail.com

Цикало Людмила Сергіївна: аспірант; Національний університет фізичного виховання і спорту України: вул. Фізкультури, 1, Київ-150, україна, 03150.

Цикало Людмила Сергеевна: аспирантка; Национальный университет физического воспитания и спорта Украины: ул. Физкультуры, 1, Киев-150, Украина, 03150.

Lyudmila Tsykalo: graduate student; National university of Physical Education and Sport of Ukraine: 1 Fizkulturna Street, Kyiv150, Ukraine, 03150.

ORCID.ORG/0000-0003-3157-9142

E-mail: milkim937@gmail.com

Бричук Марія Степанівна: к.фіз.вих.; Національний університет фізичного виховання і спорту України: вул. Фізкультури, 1, Київ-150, Україна, 03150.

Бричук Мария Степановна: к.физ.восп.; Национальный университет физического воспитания и спорта Украины: ул. Физкультуры, 1, Киев-150, Украина, 03150.

Maria Brychuk: PhD of physical education; National university of Physical Education and Sport of Ukraine: 1 Fizkulturna Street, Kyiv-150, Ukraine, 03150.

ORCID.ORG/0000-0002-9094-0527

E-mail: maxa.brychuk@gmail.com

Сімоненко Наталія Олександрівна: старший викладач кафедри фізичного виховання; Полтавський університет економіки і торгівлі: вул. Коваля 3, м. Полтава, Україна, 36014

Симоненко Наталья Александровна: старший преподаватель кафедры физического воспитания; Полтавский университет экономики и торговли: ул. Коваля 3, г. Полтава, Украина, 36014

Natalia Symonenko: senior lecturer at the Department of Physical Education; Poltava University of Economics and Trade: 3 Koval Street, Poltava, Ukraine, 36014

ORCID.ORG/0000-0003-0338-0101

E-mail: Simona17057878@gmail.com 